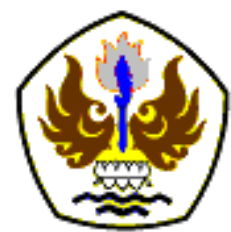

INFOMATEK

Volume 23 Nomor 1 Juni 2021

\title{
PENGEMBANGAN LAYANAN APLIKASI GO-JEK DALAM MENINGKATKAN KEPUASAN PELANGGAN
}

\author{
Suhaila Lungsae*, M. Ruslianor Maika** \\ Program Studi Perbankan Syariah \\ Fakultas Agama Islam - Universitas Muhammadiyah Sidoarjo
}

\begin{abstract}
Abstrak: Dalam penelitian ini penulis akan membahas permasalahan model bisnis berbasis ekosistem pada aplikasi Go-Jek untuk meningkatkan kepuasan dan loyalitas pelanggan. Dan pada masa terkini bahwa internet sangat mempengaruhi kehidupan masyarakat. Meningkatnya pengguna smartphone, baik Android maupun iOS, menjadikan tingkat ketergantungan masyarakat pada handphone serta internet yang tinggi. Kesempatan inilah yang mendorong para pendiri transportasi online (GO-JEK) menyediakan ojek berbasis online. Oleh karenan itu menjadi permasalahan bertujuan untuk mencari dampak ekosistem layanan dengan adanya suatu aplikasi yaitu aplikasi Go-jek. Dan juga dapat mengetahui loyalitas penggunaan aplikasi Go-jek oleh mahasiswa Universitas Muhammadiyah Sidoarjo. Metode penelitian menggunakan penelitian kualitatif pendekatan fenomenologi, bertujuan untuk mengembangkan pemahaman yang lengkap, akurat dan jelas tentang pengalaman manusia atau momen pengalaman tertentu. Dan pendekatan fenomenologi dapat mencari pengalaman pengguna secara mendalam dalam menggunakan aplikasi Go-jek. Berdasarkan hasil penelitian ini bahwa sebayak 75\% informan, merasa puas terhadap layanan mitra Go-jek, meskipun mengalami kejadian tidak sesuai dengan standar prosedur operasional Go-jek, tetapi tetap puas dengan layanan yang diberikan. Go-food merupakan layanan terbanyak yang digunakan yaitu sebanyak 36 orang, layanan kedua yang paling banyak digunakan adalah Goride sebayak 32 orang yang menggunakannya. Tingkat loyalitas pelanggan kepada mahasiswa UMSIDA cukup tinggi dengan jumlah 52\% informan dalam menggunakan aplikasi Go-jek.
\end{abstract}

Kata kunci: Layanan, Go-jek, kepuasan pelanggan, TAM

\section{PENDAHULUAN}

\subsection{Latar Belakang}

Penelitian ini dilakukan karena dua peluang utama. yang pertama, yaitu Go-jek sebagai aplikasi transportasi online terbanyak yang diminati oleh masyarakat Indonesia (Hardaningtyas, 2018 [1]) dan yang kedua,

*) suhaila0655@gmail.com

${ }^{* *}$ mr.maika@umsida.ac.id

Pertama diterima: 19 April 2021

Direvisi:18 Mei 2021

Disetujui untuk publikasi: 19 Mei 2021 inovasi Go-jek melalui model bisnis berbasis multi layanan, yang dimaksud dengan aplikasi yang menyediakan layanan dibidang transportasi. Namun tidak hanya itu, seiring berjalannya waktu Go-jek telah melakukan inovasi dalam setiap layanan yang ditawarkan. (Muhammad Adey Romadhoni, 2020 [2]) Masyarakat saat ini sangat bergantung pada ponsel (smartphone) untuk melakukan berbagai hal, antara lain untuk mencari informasi, bermain game online, hingga 
berbelanja. Selain itu ponsel juga dapat digunakan untuk memesan layanan jasa yang dilakukan secara online untuk memberikan kemudahan kepada masyarakat (Hardaningtyas, 2018 [1]). Pemakaian yang tinggi ini menuntut kualitas layanan unggul dan terkendali yang diharapkan dapat memenuhi kebutuhan pelanggan (Aji \& Hidayatullah, 2019 [3]).

Go-jek dapat menjadi salah satu perusahaan yang menggunakan sistem pemesanan online sebagai penghubung antara perusahaan dengan pelanggannya, penggunaan sistem online berbasis teknologi mobile ini untuk mendapatkan pelanggan baru dan meningkatkan nilai pelanggan. Dan Go-jek juga berusaha untuk membangun hubungan dengan pelanggan melalui memberikan pelayanan yang baik kepada pelanggannya (Aji \& Hidayatullah, 2019 [3]).

Perusahaan Go-jek berdiri pada tahun 2012 di Jakarta, Indonesia oleh Nadiem Makarim seorang pemuda kreatif yang mempunyai pemikiran untuk membuat bisnis transportasi ojek dikarenakan kebiasaan ia sering menggunakan jasa ojek (Muhammad Adey Romadhoni, 2020 [2]). Dan Nadiem Makarim berusaha untuk menemukan ide yang dapat menciptakan sarana agar jasa transportasi ojek lebih efektif dan efisien (Setiyawan, 2013 [4]).
Pengemudi Go-jek bergerak di bidang jasa dengan menguunakan speda motor serta dibekali jaket, helm, smartphone sebagai alat transportasi dan juga penggunaan aplikasi dalam melakukan pemesanannya. Masyarakat sangat puas dan senang dengan adanya transportasi online seperti Go-jek, oleh karena itu akan menjadi pemesanan yang sangat mudah dengan hanya melakukan aplikasi melalui smartphone dan harganya terjangkau (Hardaningtyas, 2018 [1]).

Kemajuan teknologi di bidang transportasi telah membuat para pebisnis berlomba-lomba untuk mendapatkan inovasi-inovasi terkini dan terbukti dari fenomena di masyarakat bahwa internet saat ini sangat berpengaruh terhadap kehidupan masyarakat. Dengan meningkatnya pengguna smartphone, baik Android maupun iOS, membuatkan masyarakat bergantung pada handphone serta internet. Kesempatan inilah yang mendorong para pendiri Ojek Online (Go-jek) akan menghadirkan ojek berbasis online (Hardaningtyas, 2018 [1]).

Fenomena transportasi online sedang ramai dibicarakan saat ini, karena pembelian aplikasi mudah di download oleh pengguna smartphone Android dan iOS. Kemudahan tersebut membuat ojek online semakin populer di kalangan masyarakat, termasuk berbagai pilihan layanan untuk memenuhi kebutuhan 
masyarakat di bidang jasa (Hardaningtyas, 2018 [1]).

Oleh karena itu, peneliti akan menghadirkan penelitian dari jenis layanan yang tersedia di dalam aplikasi Go-jek yang dapat digunakan oleh mahasiwa untuk melakukan pemesanan transportasi, makanan, dan pengiriman barang. Karena karakteristik mahasiswa pada umumnya ingin sesuatu yang instant. Maka dari itu penulis melakukan penelitian ini pada mahasiswa di Universitas Muhammadiyah Sidoarjo.

Bagi Kajian Teori adalah sebagai berikut:

1. Internet Marketing

Internet Marketing merupakan bentuk usaha bisnis baru dalam memasarkan produk atau layanan dan menjalin komunikasi dengan konsumen melalui Internet. Perkembangan internet telah menyebabkan banyak perubahan didalam masyarakat khususnya di bidang komunikasi, bahkan perkembangan internet setiap tahun telah mendatangkan lebih banyak pengguna di seluruh dunia termasuk Indonesia. Dalam hal perkembangan bisnis internet memberikan perubahan dari segi pemasaran. Hal tersebut menjadikan persaingan semakin ketat guna meningkatkan keunggulan dan kemampuan yang lebih baik untuk dapat bersaing di industri dengan berbagai strategi pemasaran yang dilakukan (Haryanto, 2008 [5]).

\section{Kepuasan Pelanggan}

Kepuasan pelanggan sangat penting dalam dunia modern ini untuk menjaga loyalitas pelanggan agar pelanggan tetap setia membeli produk atau layanan. Bagi kepuasan pelanggan sebagai penilaian seseorang atas sebuah produk dalam hasil harapan dari pelanggannya. Dan kepuasan atau ketidak puasan akan dibandingan antara hasil yang terwujudkan terhadap hasil yang diharapkan. Apabila realisasi di bawah target yang harapan maka dapat disimpulkan bahwa pelanggan mengalami ketidakpuasan. Sebaliknya jika hasil berada memenuhi dengan harapan tersebut maka dapat disimpulkan palnggan itu akan puas atas hasilnya (Murdianto, Rochmawati, \& Perdanakusuma, 2019 [6]). Dan kepuasan pelanggan juga mencakup atas perbandingan antara ekspektasi dan efisiensi yang diperolehkan. Hal tersebut terukur karena pelanggan sebagai orang yang menerima hasil pekerjaan seseorang, maka pelanggan inilah yang menentukan atas kualitas produk atau layanannya (Oliver, 2014 [7]).

\section{Pemasaran}

Kegiatan pemasaran memegang peranan yang sangat penting dalam dunia usaha. Oleh karena itu pemasaran menjadi salah satu kegiatan prioritas yang dilakukan perusahaan dalam rangka meningkatkan hasil serta mempertahankan keberlanjutan usaha 
tersebut. Selain kegiatan pemasaran, perusahaan perlu menggabungkan fungsi dan keahliannya agar dapat berkinerja dengan baik (Hafiar et al., 2018 [8]). Dan pemasaran juga merupakan suatu kegiatan dan pengelolaan yang memungkinkan individu atau kelompok untuk memperoleh apa yang diinginkan dan dibutuhkan. Hal ini dilakukan dengan menciptakan, menawarkan, dan bertukar produk berharga dengan orang lain atau semua aktivitas yang berkaitan dengan pengiriman produk atau layanan dari produsen ke konsumen (Shinta, 2011 [9]).

\section{Manajemen Pemasaran}

Manajemen pemasaran sebagai suatu usaha upaya untuk perencanaan tindakan untuk mencapai tujuan organisasi secara efektif dan efisien. Dalam fungsi manajemen pemasaran terdapat aktivitas yang menganalisis yaitu analisis untuk mengetahui pasar dan lingkungan pemasaran untuk mendapatkan seberapa besar peluang perebutan pasar dan ancaman apa yang dihadapinya (Bitar, 2014 [10]).

\section{Layanan}

Layanan sebagai suatu tindakan atau sifat yang dapat ditawarkan oleh satu pihak kepada pihak lain yang tidak berwujud dan tidak menghasilkan kepemilikan apa pun. Dan layanan juga sebagai kunci sukses dalam bisnis apapun dalam kegiatan pelayanan.
Perannya akan semakin besar dan aktivitas layanan ini dinilai cukup ketat dalam upaya merebut pangsa pasar atau pelanggannya. Oleh karena itu, dalam lingkungan persaingan yang ketat, setiap perusahaan mampu memberikan layanan berkualitas untuk mempertahankan loyalitas anggotanya.

Dalam penelitian ini pemasaran layanan juga menyebutkan bahwa layanan akan memiliki beberapa karakteristik tersebut, seperti Komposisi produk, tempat dan waktu, proses, produk, kualitas, orangnya, promosi dan pendidikan, bukti fisik, harga dan biaya pengguna lainnya (Muhammad Adey Romadhoni, 2020 [2]).

\section{Loyalitas Pelanggan}

Perilaku konsumen sebagai bagian dari aktivitas manusia seringkali berubah sesuai dengan pengaruh lingkungan dan social dimana mereka berada. Namun perilaku konsumen yang diharapkan bagi suatu perusahaan adalah loyalitas, yaitu loyalitas yang berarti pelanggan terus berbelanja secara rutin. Dan bagi loyalitas pelanggan secara umum dapat didefinisikan sebagai kesetiaan terhadap produk dan layanan tertentu. Loyalitas pelanggan adalah sebagai dorongan perilaku pembelian secara berulangulang, dan membangun loyalitas pelanggan terhadap produk atau layanan yang dihasilkan oleh bisnis memerlukan proses pembelian berulang dengan waktu yang lama. Loyalitas 
pelanggan memliki peranan penting dalam sebuah perusahaan, mempertahankannya berarti meningkatkan kinerja keuangannya dan menjaga kelangsungan perusahaan, inilah alasan utama yang menarik dan dipertahankannya oleh mereka (li \& Pelanggan, 2005 [11]).

\subsection{Rumusan Masalah}

Dengan didasari munculnya permasalahan yang telah dijelaskan diatas maka rumusan masalah pada penelitian ini adalah bagaimana kualitas layanan yang diberikan oleh mitra Gojek dapat menarik minat kosumen yang menggunakan jasa layanan dari Go-jek.

\subsection{Tujuan Dalam Penelitian}

Berdasarkan dari masalah yang ada di atas, penelitian ini bertujuan untuk menganalisis kualitas layanan yang diberikan mitra Go-jek dan multi layanan yang ada dalam aplikasi Go-jek.

\section{METODOLOGI}

Dalam penelitian ini metode yang digunakan yaitu metode kualitatif dilakukan untuk mencari informasi tentang pengalaman mahasiswa dalam menggunakan aplikasi Transportasi online (Go-Jek) yang terkait tingkat kepuasan saat menggunakan aplikasi tersebut. Oleh karena itu peneliti akan melakukan penelitian langsung kepada mahasiswa yang menggunakan transportasi online ini.
Sedangkan yang dilakukan pada penelitian ini adalah pendekatan fenomenal bertujuan untuk mengembangkan deskripsi yang lengkap, akurat dan jelas, serta memahami pengalaman manusia atau momen spesifik dari pengalaman tersebut.

Situasi sosial terdiri dari tiga komponen utama yaitu lokasi, pelaku, dan kegiatan. Bagi fasilitas penelitian terletak di Universitas Muhammadiyah Sidoarjo. Pelaku dalam penelitian ini adalah mahasiswa Universitas Muhammadiyah Sidoarjo yang menggunakan Go-Jek, sedangkan kegiatan yang diteliti adalah penggunaan aplikasi Go-Jek. Bagi jenis dan sumber data yang peneliti digunakan data perimer dan data sekunder. Data perimer ini merupakan data yang dapat diperoleh dengan melakukan wawancara secara langsung. Sedangkan data sekunder merupakan data yang peneliti dapatkan melalui jurnal. Teknik mengumpulan data peneliti akan dilakukan melalui wawancara yang tidak terstruktur. Penelitian dilakukan dengan wawancara terhadap responden tidak terstruktur untuk menggali pengalaman dan perspektif dari informan. Daftar pertanyaan yang diajukan kepada informan disusun sebelum wawancara dilaksanakan. Dalam wawancara tersebut narasumber akan membagikan semua layanan yang disediakan didalam aplikasi Go-jek. Daftar pertanyaan ini berfungsi untuk membatasi proses wawancara 
agar tidak berkembang ke arah lain. Alasan khusus penentuan responden yang berasal dari Universitas Muhammadiyah Sidoarjo dikarenakan jumlah mahasiswa yang banyak dan juga sebagian besar mahasiswa UMSIDA yang menggunakan aplikasi Go-jek. Jumlah responden yaitu 40 mahasiswa UMSIDA yang menggunakan aplikasi Go-Jek.

Pengolahan data kualitatif yang diperoleh dilakukan menggunakan software ATLAS.ti. Software tersebut membantu untuk memproses dalam bentuk wawancara, observasi dan dokumen lainnya baik dalam format audio maupun gambar dan akan disajikan dalam bentuk deskipsi Technology Acceptance Model (TAM) dengan menggunakan empat bentuk utama yaitu perceived usefulness, perceived ease of use, attitude towards using technology, behavioral intention.

\section{ANALISIS DAN PEMBAHASAN}

\subsection{Hasil Penelitian}

Hasil dari wawancara yang telah peneliti dengan dilakukan kepada 40 informan akan menunjukkan layanan yang paling banyak digunakan oleh pelanggan adalah gofood, go ride, gocar. Bagi gofood yang digunakan sebanyak 36 informan, gocar sebanyak 32 informan, dan selajutnya gocar sebanyak 18 informan. Disini akan melihat 3 layanan ini adalah layanan yang sering di gunakan oleh pelanggan.

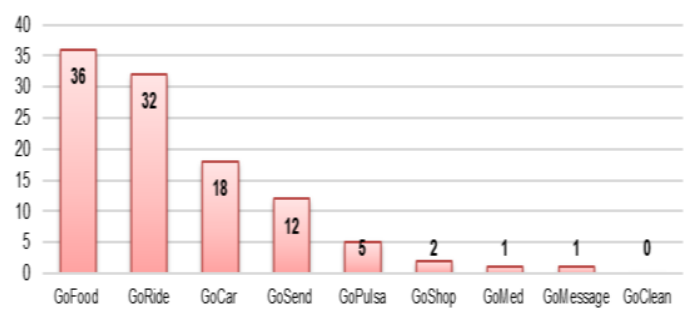

\section{Gambar 1}

Layanan aplikasi Go-jek yang sering digunakan

Selain itu pelanggan juga pernah menggunakan layanan yang tersedia di aplikasi Go-jek seperti gosend sebanyak 12 informan, gopulsa sebanyak 5 informan, goshop sebanyak 2 informan. Dan bagi layanan yang digunakan paling sedikit oleh pelanggan adalah gomed dengan gomessage kedua-duanya ini digunankan yang paling sedikit dari layanan Go-jek sebanyak 1 informan. Sedangkan layanan yang tidak pernah digunakan oleh pelanggan adalah goclean.

\subsubsection{Jenis Kelamin Informan}

Dari hasil wawancara dengan dilakukan oleh penulis yang berdasarkan jenis kelamin informan, disini akan dijelaskan berupa grafik sebagaimana diperlihatkan pada Gambar 2. 


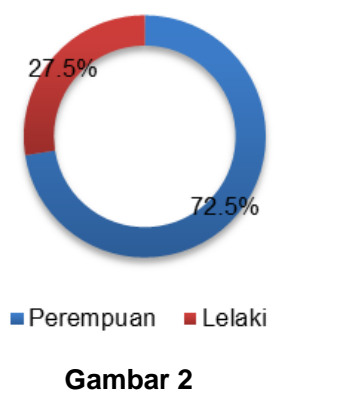

Jenis Kelamin dari penggunaan aplikasi Go-jek

Gambar 2 menunjukkan bahwa jenis kelamin perempuan lebih banyak daripada kelamin lelaki sebanyak $72,5 \%$. Kemudian jenis kelamin lelaki mempunyai sebanyak 27,5\% dikarenakan Go-Jek hadir menawarkan hal yang di dambakan di seluruh lapisan masyarakat, khusunya bagi mereka yang memiliki smartphone yang sudah diintegrasi dengan aplikasi Go-Jek. Begitu pula yang terjadi di kalangan Mahasiswa Universitas Muhammadiyah Sidoarjo. Go-Jek telah menjadi trend transportasi pada saat ini di kalangan Mahasiswa Universitas Muhammadiyah Sidoarjo. Go-Jek bukan saja dimanfaatkan, sebagaimana kegunaan ojek pada umumnya, melainkan di peruntukkan untuk keperluan lainnya. Dan bagi aplikasi GoJek juga menyediakan beberapa jasa layanan lainnya sesuai kebutuhan penggunannya.

\subsubsection{Kegiatan Informan}

Dari hasil wawancara dengan dilakukan oleh penulis yang berdasarkan jenis kegiatan informan, disini akan dibuatkan menjadi 2 kategori adalah kelas perkuliahan yaitu kelas pagi dengan kelas malam, kemudian akan dijelaskan berupa grafik sebagai berikut:

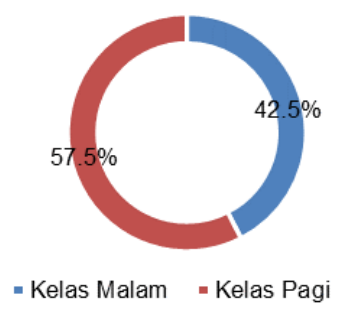

Gambar 3

Kegiatan informan dari penggunaan aplikasi Go-jek

Pada Gambar 3 dari hasil wawancara data yang penulis dilakukan akan menunjukkan bahwa kegiatan informan pada kelas pagi menegalami persentase sebanyak 57,5\%. Kemuadian kegiatan pada kelas malam mengalami sebanyak 42,5\%. Disini juga akan melihat dengan kelas pagi lebih mendominasi dari pada kelas malam, dikarenakan kelas pagi akan dimulai kuliah dari pada jam pagi sampai waktu siang kemudian waktu istirihat mahasiswa kebanyakan mengguna layanan aplikasi Go-jek untuk pesan gofood buat makanan siang. Sedangkan kelas malam kebanyakan mahasiswa yang kerja, jadi kurang menggunakan layanan aplikasi Go-jek. Dari hasil diatas penulis akan dilakukan wawancara oleh 40 informan. Terdapat pada kegiatan perkuliahan kelas malam mengalami 20 informan yang status bekerja. Sedangkan bagi kegiatan perkuliahan kelas pagi mengalami 20 informan yang status belum kerja hanya melakukan perkuliahan saja. 


\subsubsection{Kualitas Layanan}

Hasil dari penelitian bahwa penulis akan dilakukan mengenai pengalaman bagi penggunaan layanan aplikasi Go-jek terdapat yang pernah mengalami pelayanan yang kurang baik dari mitra pengemudi Go-jek sebanyak $40 \%$ informan. Sedangkan bagi yang belum pernah mengalami pelayanan yang kurang baik dari mitra pengemudi Go-jek sebanyak 60\%. Disini akan terlihat bahwa pelanggan diatas kebanyakan belum pernah mengalami yang kurang baik dikarenakan sebagian besar informan dilayani dengan baik oleh mitra pengemudi Go-jek.

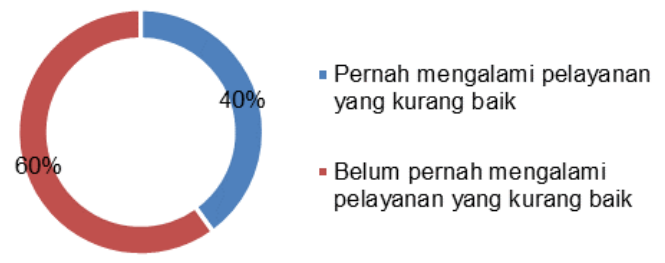

Gambar 4

Kualitas Layanan

Dari beberapa hal tersebut diatas membuatkan konsumen tidak puas dalam mengalami layanan aplikasi Go-jek yang diberikan oleh para mitra pengemudi. Meskipun ada yang tidak pernah mengalami yang tidak baik dapat disimpulkan bahwa standar operasional prosedur dari penyediaan jasa layanan Go-jek akan tidak diterapkan oleh semua mitra pengemudi.

\subsubsection{Kepuasan Pelanggan}

Gambar 5 memperlihatkan hasil survey mengenai tingkat kepuasan pelanggan.

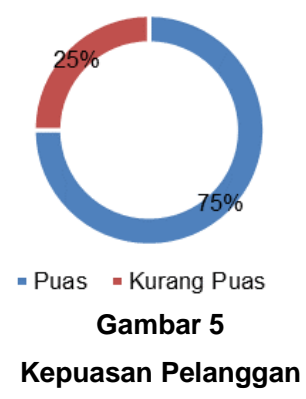

Dari hasil di atas dalam pengolahan data primer, dapat dinyatakan bahwa informan merasa puas dalam layanan yang diberikan oleh mitra pengemudi Go-jek sebanyak $75 \%$. Kemudian bagi informan yang kurang puas dalam layanan aplikasi Go-jek sebanyak 25\%. Oleh karenan itu, dapat disimpulkan bahwa layanan aplikasi Go-jek pada saat terkini menjadi teknologi aplikasi online yang ditawarkan sebuah jasa transportasi yang murah, cepat dan mudah digunakan bagi konsumen.

\subsection{PEMBAHASAN}

Hasil data wawancara 40 informan akan peneliti oleh penulis, data wawancaranya ada dalam betuk audio salajutnya penetili akan dirubah data bentuk audio menjadi bentuk teks. Teks wawancara juga diolah menggunakan bantuan oleh software Atlas.ti. 


\subsubsection{Perceived Usefulness}

Gambar 6 merupakan data hasil dari penulis yang dipengolahan dalam bentuk software ATLAS.ti akan menunjukkan sebuah persepsi kegunaan (perceived usefulness). Bahwa bagi tingkat loyalitas konsumen yang menggunakan layanan aplikasi Go-jek secara aktif menjadi tergolong tinggi oleh mahasiswa Unversitas Muhammadiyah Sidoarjo.

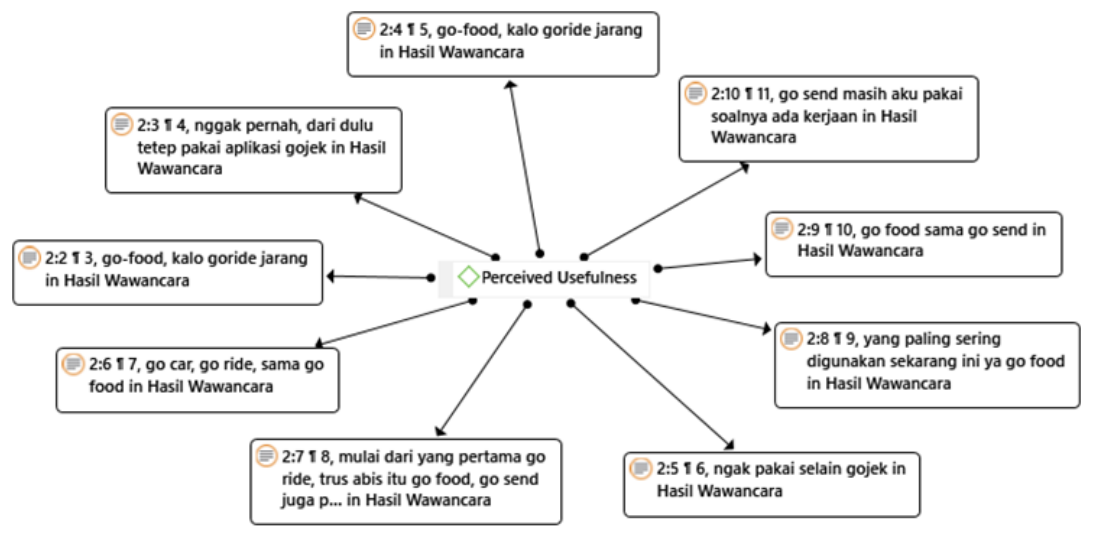

Gambar 6

Hasil Network Perceived Usefulness

Mayoritas informan setia dalam menggunakan layanan aplikasi Go-jek, meskipun sudah pernah menggunakan layanan selain Go-jek. Dan membuat mayoritas menggunakan layanan aplikasi Go-jek lebih dari 2 tahun, oleh karena itu membuat mayoritas tetap menggunakan layanan aplikasi Go-jek kembali, bagi konsumen juga akan mendapat pelayanan yang terbaik dari pengemudi Gojek.

Dari hasil wawancara dapat disimpulkan bagi informan yang menggunakan layanan aplikasi Go-jek secara aktif mempunyai persentase sebesar $52 \%$ atau lebih dari pada 20 informan dalam menggunan layanan aplikasi Go-jek untuk melakukan pemesanan.

Sedangkan bagi yang tidak aktif mempunyai persentase sebesar $48 \%$ dalam mengalami kegunaan layanan aplikasi Go-jek. Oleh karena itu dari hasil diatas layanan yang paling banyak digunakan bagi konsumen adalah gofood kemudian bagi layanan yang terbanyak selanjutnya adalah goride, bagi kedua-duanya layanan tersebut merupakan layanan yang paling sering digunakan oleh konsumen 
3.2.2. Perceived Ease of Use

pengguna (perceived ease of use) dalam Hasil network pada Gambar 7 diolah layanan aplikasi Go-jek memberikan menggunakan software ATLAS.ti kemudahan bagi konsumen.

menunjukkan bahwa persepsi kemudahan

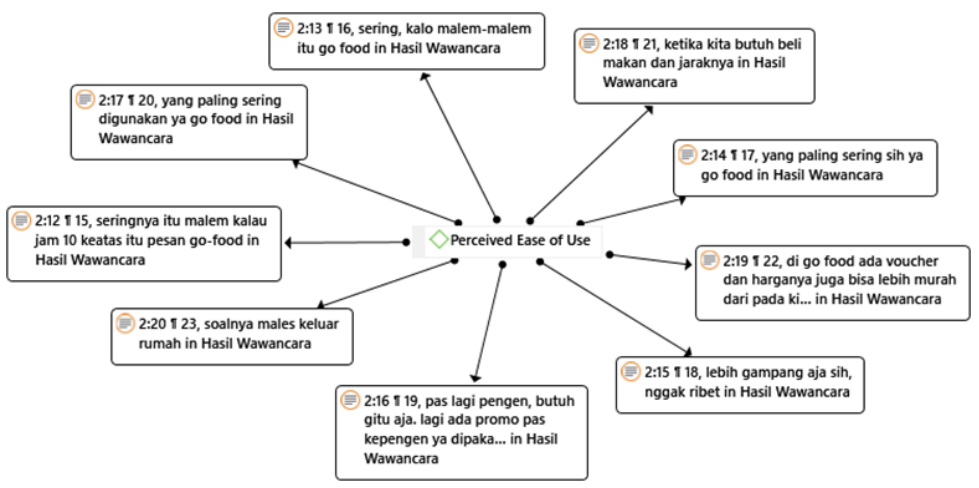

Gambar 7

Hasil Network Perceived Ease of Use

Transportasi online tidak hanya memberi kemudahan dalam layanan pemesanan makanan saja, namun juga menawarkan layanan gosend dan gobox untuk memberikan kemudahan dalam pengiriman barang. Layanan yang dapat dalam wawancara diatas bahwa semua layanan dalam aplikasi Go-jek akan diberi kemudahan kepada konsumen.

Dalam persepsi kemudahan pengguna layanan aplikasi Go-jek oleh konsumen dapat disimpulkan bahwa layanan yang paling banyak digunakan adalah gofood dikarenakan konsumen malas keluar dari rumah untuk membeli makanan, itu merupakan mayoritas alasan penting bagi konsumen yang diwawancara oleh penulis dalam menggunakan layanan gofood. Dan layanan inilah dapat memberikan kemudahan bagi konsumen dalam pemesanan makanan, maka juga diberikan kemudahan bagi konsumen yang butuh makanan dengan jaraknya jauh, dengan hanya melakukan pemesanan dirumah ataupun dimana saja.

Pelayanan yang diberikan oleh konsumen menyatakan bahwa merasa nyaman untuk menggunakan dan juga memberi kemudahan bagi semua konsumen dalam menggunakan pelayanannya, itu adalah salah satu alasan baik dari fitur aplikasi Go-jek maupun pelayanan dari pengemudi Go-jek. 


\subsubsection{Attitude Towards Using Technology}

Gambar 8 memperlihatkan hasil wawancara kepada responden mengenai sikap terhadap teknologi. Dari hasil wawancara ini menunjukkan bahwa pengalaman yang didapatkan oleh konsumen dalam sikap menggunakan teknologi (Attitude towards using technology).

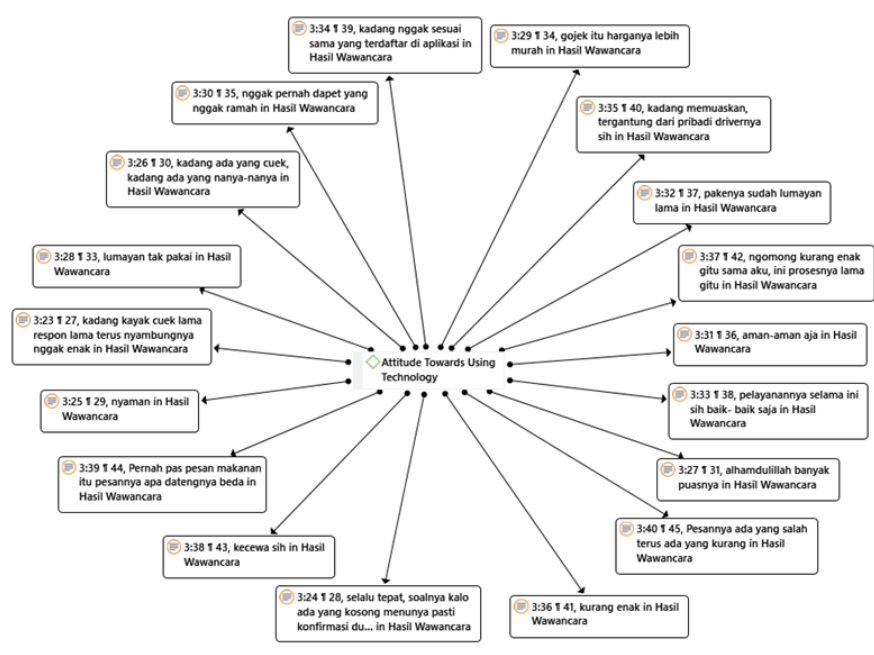

Gambar 8

Hasil Network Attitude Towards Using Technology

Pengalaman yang dapatkan dari konsumen akan memberi memuaskan setelah mengunakan aplikasi Go-jek sebagaimana para mitra pengemudi Go-jek bersikap sopan dengan konsumen, menghantar barang kepada konsumen sesuai yang terdaftar dalam layanan aplikasi Go-jek dan selalu tepat bagi menu yang kosong para mitra pengemudi Go-jek pasti konfirmasi terlebih dahulu. Kemudian bagi saat diperjalanan driver dari Go-jek sering mengajakkan berbincangbincang. Oleh karena itu, pengalaman yang didapatkan diatas membuat konsumen merasa senang dan suka dalam menggunakan layanan aplikasi Go-jek.
Selain mendapat pengalaman yang memuaskan diatas, maka informan juga merasa hal yang lain yaitu pengalaman yang kurang memuaskan selama menggunakan layanan aplikasi Go-jek, bagi pengalaman yang kurang memuaskan diantaranya adalah kurangnya komunikasi dan kurangnya sopan oleh para mitra pengemudi Go-jek dengan konsumen, setelah itu makanan yang dipesan tidak sesuai yang terdaftar dalam layanan aplikasi Go-jek kemudian kadang-kadang datangnya beda dari pemesanannya. Beberapa hal tersebut diatas membuat konsumen kecewa dan kurang memuaskan oleh sistem yang ada dalam layanan aplikasi 
Go-jek. Dan membuat konsumen merasa dirugikan dengan kajadian tersebut.

Pengolahan hasil wawancara tersebut menunjukkan bahwa minat perilaku (behavioral intention) dengan adanya

\subsubsection{Behavioral Intention} teknologi.

Gambar 9 memperlihatkan hasil wawancara kepada responden mengenai minat perilaku.

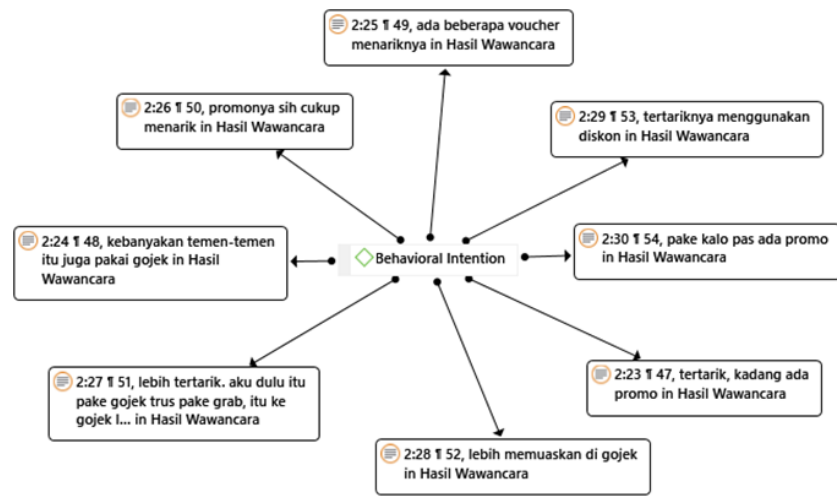

Gambar 9

Hasil Network Behavioral Intention

\section{Responden merasakan bagaimana} kemudahan diterima oleh konsumen dalam menggunakan layanan aplikasi Go-jek. Oleh karena itu yang tertarik bagi konsumen dalam menggunakan aplikasi Go-jek adalah promosi yang ditawarkan dalam layanannya. Kadangkadang adanya diskon dari layanan gofood. Layanan tersebut membuat konsumen tertarik dalam pemesanannya. Sedangkan kalau tidak ada promosi dari layannannya maka tidak akan tertarik oleh konsumen untuk menggunakan semua layanan yang tersedia dari Go-jek. Selanjutnya dari penelitian ini penggunaan oleh konsumen dapat lebih dari menyesuaikan kebutuhan hidup. Kemudian bagi layanan yang tidak menyesuaian kebutuhan hidup maka kurang digunakan oleh konsumen.

Dari hasil network di atas dapat disimpulkan bahwa konsumen dapat memuaskan dan tertarik dalam menggunakan layanan aplikasi Go-jek ketika ada promosi dari layanannya. Oleh karena itu tranportasi online ini berfokus pada inovasi dibandingkan promosi seperti cashback dan diskon. Dengan begitu, menjadi optimasi bagi pelayanan yang lebih sering digunakan oleh konsumen. 


\section{KESIMPULAN}

Dalam kemajuan teknologi di bidang transportasi telah membuat para pebisnis berlomba-lomba untuk mendapatkan inovasiinovasi pada saat ini dan terbukti dari fenomena di masyarakat bahwa internet saat ini sangat berpengaruh terhadap kehidupan masyarakat. Dengan meningkatnya pengguna smartphone, baik Android maupun iOS, akan membuatkan masyarakat bergantung pada handphone serta internet. Kesempatan inilah yang mendorong para pendiri transportasi online (GO-JEK) akan menghadirkan ojek berbasis online dengan namanya aplikasi Gojek.

Berdasarkan hasil penelitian ini dapat disimpulkan bahwa sebayak $75 \%$ informan yang merasa puas terhadap layanan mitra Gojek, meskipun pernah mengalami kejadian tidak sesuai dengan standar prosedur operasional Go-jek, tetapi tetap puas dengan layanan yang diberikan. Bagi layanan yang paling banyak digunakan adalah go-food sebayak 36 orang, layanan kedua yang paling banyak digunakan adalah Go-ride sebayak 32 orang yang menggunakannya. Tingkat loyalitas pelanggan kepada mahasiswa Universitas Muhammadiyah Sidoarjo cukup tinggi dengan jumlah 52\% informan dalam menggunakan aplikasi Gojek.

\section{DAFTAR PUSTAKA}

[1] Hardaningtyas, R. T. (2018). Persepsi Masyarakat Terhadap Penggunaan Transportasi Online (Grab) Di Malang. INOBIS: Jurnal Inovasi Bisnis Dan Manajemen Indonesia, 2(1), 42-58. https://doi.org/10.31842/jurnalinobis.v2i1.60

[2] Muhammad Adey Romadhoni. (2020). Analisis Model Bisnis Multi Layanan Pada Aplikasi Go-Jek Dalam Meningkatkan Kepuasan Pelanggan. Osteoarthritis and Cartilage, 28(2), 1-43. Retrieved from http://journals.sagepub.com/doi/10.1177/ 1120700020921110\%0Ahttps://doi.org/1 0.1016/j.reuma.2018.06.001\%0Ahttps://d oi.org/10.1016/j.arth.2018.03.044\%0Ahtt ps://reader.elsevier.com/reader/sd/pii/S1 063458420300078?token=C039B8B139 22A2079230DC9AF11A333E295FCD8

[3] Aji, S., \& Hidayatullah, A. (2019). Analisis Kepuasan Pelanggan Terhadap Kualitas Pelayan Aplikasi Gojek Dengan Metode PIECES Framework. Jurnal Sistem Informasi, $x, 1-7$. Retrieved from http://ojs.stmik-borneo.ac.id/index.php/JSIm/article/view/46

[4] Setiyawan. (2013). GAMBARAN UMUM PT. GOJEK INDONESIA Sub. Journal of Chemical Information and Modeling, 53(9), 1689-1699.

[5] Haryanto, E. (2008). Edy Haryanto, 
Teknologi Informasi dan Komunikasi: Konsep dan Perkembangannya. Pemanfaatan Teknologi Informasi dan Komunikasi Sebagai Media Pembelajaran.,Andi, Yogyakart 2008. hlm 1201 digilib.uinsby.ac.id digilib.uinsby.ac.id digilib.uinsby.ac.id digilib. 1-21.

[6] Murdianto, Y., Rochmawati, R. I., \& Perdanakusuma, A. R. (2019). Analisis Pengaruh Layanan Terhadap Kepuasan Pelanggan Menggunakan Metode Servqual (Studi Kasus Go-Jek Kota Malang). Jurnal Pengembangan Teknologi Informasi Dan IImu Komputer, 3(1), 603-612.

[7] Oliver. (2014). Kepuasan Pelanggan Kotler. 8-25.

[8] Hafiar, H., Lukman, S., Ardiyanto, A.,
Basu, S., Irawan, Mussardo, G., ... Mussardo, G. (2018). LANDASAN TEORI PEMASARAN. Statistical Field Theor, 53(9), 1689-1699.

[9] Shinta, A. (2011). Manajemen Pemasaran Strategis. In Perpustakaan Nasional: Katalog dalam Terbitan.

[10] Bitar. (2014). Pengertian Manajemen Pemasaran, Fungsi, Tujuan, Konsep \& Contoh. Retrieved December 5, 2020, from GuruPendidikan.Com website: https://www.gurupendidikan.co.id/manaje men-pemasaran/

[11] li, B. A. B., \& Pelanggan, A. L. (2005). Loyality is defined as non random purchase expressed over time by some decision making unit. 28-47. 